\title{
Modelowanie mikrosejsmiczne narzędziem wspomagania rozpoznawania i interpretacji geologicznej ośrodka oraz monitorowania efektów szczelinowania hydraulicznego
}

\begin{abstract}
W artykule przedstawiono wyniki obliczeń uzyskanych autorskim programem MICROMOD 3D, opracowanym w ramach realizacji programu Blue Gas - projekt GASLUPMIKROS. Otrzymane rezultaty należy traktować jako testowanie ogólności zaproponowanego rozwiązania, szczegółowo opisanego w publikacji [1]. Testowanie prowadzono na modelach teoretycznych, stworzonych na podstawie rzeczywistych danych pozyskanych na jednej z koncesji PGNiG. Komentarz dotyczący wyników dla kolejnych modeli odnosi się raczej do metodyki funkcjonalnej programu, która zapewnia możliwość zastosowania go dla 3 najczęściej realizowanych wersji monitoringu sejsmicznego (powierzchniowego, otworowego oraz odbiorników pogrążonych). Przedstawione rezultaty pozwalają pozytywnie ocenić opracowany program oraz rekomendować jego wykorzystanie w bieżących pracach przemysłowych, zarówno w projektowaniu akwizycji dla mikroszczelinowania hydraulicznego, jak też przy weryfikacji obliczanych parametrów geomechanicznych ośrodka geologicznego. Ponadto wyniki modelowań standardowo stanowią wsparcie dla prac interpretacyjnych sejsmiki.
\end{abstract}

Słowa kluczowe: fale mikrosejsmiczne, model mechaniczny, tensor naprężeń, parametry wytrzymałości skał, modelowanie pola sprężystego, szczelinowanie hydrauliczne.

\section{Microseismic modeling as a support for prospection, interpretation of geological media and monitoring of hydraulic fracturing}

\begin{abstract}
In the paper the results of calculations obtained by way of the Micromod 3D software, developed as part of the Blue Gas project - GASLUPMIKROS are presented. These results should be treated as general testing of the proposed solution, described in detail in the publication [1]. Testing was conducted on theoretical models, created on the basis of real data, obtained from one of the PGNiG concessions. Comments on the results for the following models refers rather to the methodology of the software functionality, which provides the ability to use the Micromod 3D for the three most frequently performed types of the seismic monitoring: surface sensor network, downhole sensors, and shallow buried array. The results allow to positively evaluate the developed software and recommend its use in the ongoing work in the industry, both in the design of acquisition for hydraulic fracturing as well as the verification of calculated geomechanical parameters of geological medium. Furthermore, the microseismic modeling results provides support for seismic interpretation.
\end{abstract}

Key words: microseismic, seismic modeling, microseismic modeling, acquisition parameters, hydraulic fracturing, microseismic monitoring.

\section{Wprowadzenie}

Jak wspomniano w poprzedzającym niniejszą publikację artykule pt. Mikrosejsmika, sejsmika, sejsmologia - wspólne korzenie, różne cele, zintegrowane działania [1], predykcja pola mikrosejsmicznego jest znacznie trudniejsza niż w przypadku typowego pola sejsmicznego sejsmiki refleksyjnej. W metodzie sejsmicznej, znając podstawowe parametry ośrodka 
geologicznego (geometrię, głębokości, prędkości), jesteśmy w stanie oszacować rząd wielkości czasu występowania refleksów, a nawet ich amplitudy (oczywiście wtedy, gdy nie występują silne zakłócenia).

W metodyce mikrosejsmiki oszacowanie jest prawie niemożliwe, przede wszystkim ze względu na zróżnicowanie energii generowanej przez kolejne szczelinowania hydrauliczne. Stąd możliwość modelowania pola mikrosejsmicznego nawet przy uwzględnieniu przybliżonych zaledwie parametrów ośrodka oddaje nieocenione usługi w procesie projektowania schematu akwizycji monitorowania. Może być ono także wykorzystywane przy interpretacji mikrowstrząsów, np. do wyznaczania parametrów mechanicznych ośrodka.

\section{Testowanie programu MIKROMOD i analiza uzyskanych wyników - na przykładzie opracowanych modeli}

Dość szczegółowe przedstawienie wprowadzania parametrów sterujących dla programu MIKROMOD 3D ma na celu pokazanie dużej wszechstronności opracowanego sposobu modelowania, pozwalającego na operowanie różnymi schematami akwizycji, zastosowanymi w konkretnych przypadkach monitorowania mikrosejsmicznego. Równocześnie pozwala w miarę obiektywnie ocenić skuteczność sposobu monitorowania w odniesieniu do określenia parametrów mechanicznych ośrodka.

Wykonane modelowania świadczą $\mathrm{z}$ jednej strony o dużym relatywizmie wyników (małe zmiany parametrów silnie wpływają na obliczane wielkości i odwrotnie), z drugiej strony ukazują dominujący wpływ budowy ośrodka na efektywność szczelinowania, co jest właściwie oczywiste, ale jednocześnie utrudnia klasyfikację ośrodka w tym aspekcie, uwypuklając rolę modelowania, co pokazane zostało na kolejnych przykładach.

Przywołując przedstawiony w publikacji pt. Mikrosejsmika, sejsmika, sejsmologia - wspólne korzenie, różne cele, zintegrowane dziatania [1] opis modelu 2 i reali- zacji obliczeń, widzimy, iż dla czterech aktywnych powierzchni przyjęto odcinek szczelinowania równy $800 \mathrm{~m}$ (opcja - przebieg promienia w górę), usytuowany na głębokości $z=3200 \mathrm{~m}$. Punkty szczelinowania (stage) przesuwano z krokiem 100 m, a więc uzyskano dziewięć stacji wzbudzenia. Z każdej z nich zarejestrowano trzy odbicia od granic aktywnych. Bardzo korzystną cechą rozwiązania jest możliwość sprawdzenia wyników propagacji zależnie od położenia horyzontu szczelinowanego.

Przy przebiegu promienia w górę wzbudzenie (szczelinowanie) dokonuje się na głębokości $z=3200 \mathrm{~m}$, drgania propagują ku powierzchni $z=0,0 \mathrm{~m}$ i wracają (odbicie) do punktu wzbudzenia. Przesuwanie się punktu wzbudzenia (PW) dokonuje się wzdłuż osi $Y$, od $Y_{0}=2,138 \mathrm{~km}$ do $Y_{n}=2,938 \mathrm{~km}$ (czyli o wspomniane już $800 \mathrm{~m}$ ). W przypadku kolejnych granic pozycja punktu wzbudzenia jest oczywiście identyczna, zmienia się całkowita droga promienia odbitego $R[\mathrm{~km}]$ oraz czas propagacji $T$ [s].

Dla omawianego uprzednio modelu 2 i punktu wzbudzenia o współrzędnych $\left\{X_{0}, Y_{0}, Z_{0}\right\}=\{1,850 ; 2,138 ; 3,200\}$

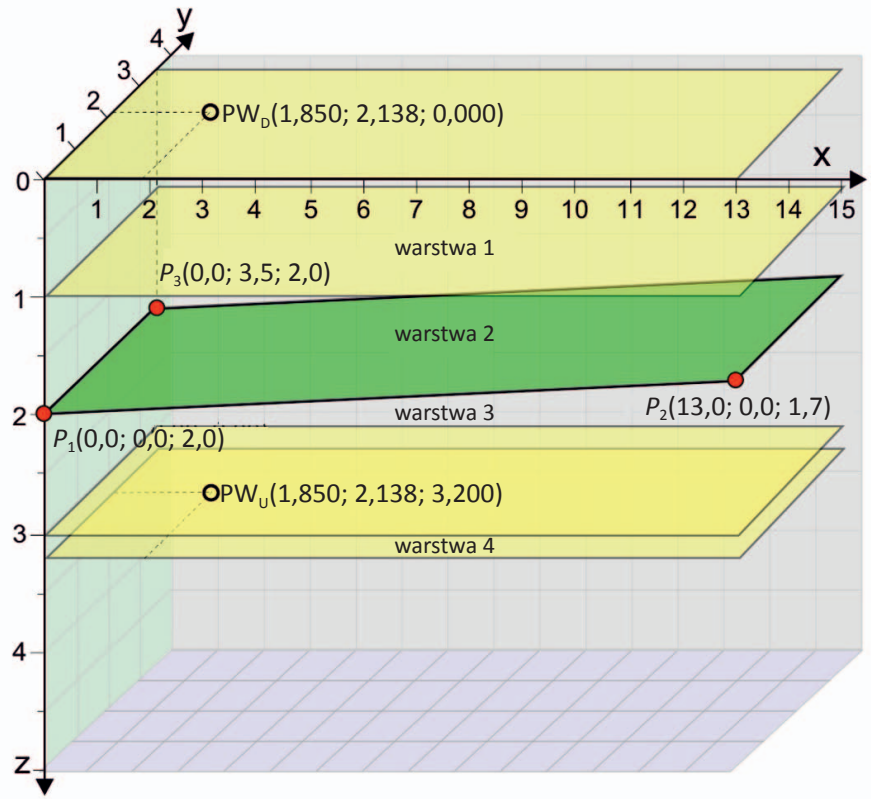

Powierzchnie modelu 2 opisano równaniami, jak niżej:

\begin{tabular}{|c|c|c|c|c|c|c|}
\hline Powierzchnia & $A x$ & $+B y$ & $+C z$ & $+D$ & $=0$ & \\
\hline 1 & 0,0 & 0,0 & 1,0 & 0,0 & & $z=0$ \\
\hline 2 & 0,0 & 0,0 & 1,0 & $-1,0$ & & $z=-1$ \\
\hline 3 & 1,05 & 0,0 & 45,5 & $-91,0$ & & $\begin{array}{l}\text { granica nachylon } \\
1,7 \leq z \leq 2\end{array}$ \\
\hline 4 & 0,0 & 0,0 & 1,0 & $-3,0$ & & $z=-3$ \\
\hline 5 & 0,0 & 0,0 & 1,0 & $-3,2$ & & $z=-3,2$ \\
\hline
\end{tabular}

natomiast prędkości i gęstości są następujące:

\begin{tabular}{|c|c|c|}
\hline Nr warstwy & $V[\mathrm{~m} / \mathrm{s}]$ & $\rho\left[\mathrm{g} / \mathrm{m}^{3}\right]$ \\
\hline 1 & 2600 & 2,14 \\
\hline 2 & 3000 & 2,35 \\
\hline 3 & 3500 & 2,40 \\
\hline 4 & 4000 & 2,35 \\
\hline
\end{tabular}

Geometria modelu 2 (liczba warstw: 4; liczba powierzchni rozgraniczających: 5) 
oraz promienia sterującego $r=0,0 \mathrm{~m}$ i kąta azymutu $\varphi=0^{\circ}$ całkowita droga $R[\mathrm{~km}]$ i czas propagacji $T$ [s] od kolejnych granic wynoszą:

\begin{tabular}{|c|c|c|c|c|}
\hline & 1. granica & 2. granica & 3. granica & \\
\hline$R[\mathrm{~km}] \rightarrow$ & 2,000 & 3,916 & 6,000 & \multirow{2}{*}{$\begin{array}{l}\text { propagacja } \\
\text { „W dół” }\end{array}$} \\
\hline $2 T[\mathrm{~s}] \quad \rightarrow$ & 0,7692 & 1,4081 & 2,0033 & \\
\hline$R[\mathrm{~km}] \rightarrow$ & 2,400 & 2,487 & 4,400 & \multirow{2}{*}{$\begin{array}{l}\text { propagacja } \\
\text { „W górę" }\end{array}$} \\
\hline $2 T[\mathrm{~s}] \quad \rightarrow$ & 0,600 & 0,6605 & 1,2983 & \\
\hline
\end{tabular}

natomiast dla kolejnej pozycji szczelinowania $r=800 \mathrm{~m}$ i azymutu $\varphi=0^{\circ}$ są następujące:

\begin{tabular}{|l|c|c|c|c|}
\cline { 2 - 4 } \multicolumn{1}{c|}{} & 1. granica & 2. granica & 3. granica & \multicolumn{1}{c}{} \\
\cline { 1 - 4 } \multicolumn{1}{c|}{$[\mathrm{km}] \rightarrow$} & 2,561 & 5,326 & 9,177 & propagacja \\
\cline { 1 - 4 } $2 T[\mathrm{~s}] \rightarrow$ & 0,9851 & 1,9066 & 3,0070 & „W dół” \\
\cline { 1 - 4 }$[\mathrm{km}] \rightarrow$ & 2,884 & 2,926 & 5,030 & propagacja \\
\cline { 1 - 4 } $2 T[\mathrm{~s}] \rightarrow$ & 0,7211 & 0,7758 & 1,4772 & "W górę" \\
\hline
\end{tabular}

Powyższe wartości potwierdzone są w tablicy 1 (a, b, c, d). Przytoczenie oryginalnych tablic z wynikami obliczeń ma na celu przybliżenie koncepcji programowej, natomiast ekstrakcja wybranych wartości z tabel jest pomocą w interpretacji logicznej wyników.

Z powyższego wynika, że wybór geometrii schematu akwizycji może skutkować bardziej lub mniej dokładną interpretacją.

Warto zauważyć, co może być ważne dla metodyki szczelinowania hydraulicznego, że w przypadku zadeklarowanego modelu o głębokości rzędu ponad $3 \mathrm{~km}$ przyjęcie zbyt małych odległości pomiędzy kolejnymi pozycjami szczelinowania nie pozwala na dokładną interpretację zdarzeń mikrosejsmicznych w przestrzeni. Zróżnicowanie drogi promienia i czasu propagacji w zależności od azymutu jest prawie niezauważalne (pomimo upadu jednej z granic).

Dla odległości szczelinowania $r=0,0 \mathrm{~m}$ i azymutu $\varphi=270^{\circ}$ całkowite drogi promienia i czasy wynoszą:

\begin{tabular}{|c|c|c|c|c|}
\hline & 1. granica & 2. granica & 3. granica & \\
\hline$R[\mathrm{~km}] \rightarrow$ & 2,000 & 3,916 & 6,000 & \multirow{2}{*}{$\begin{array}{l}\text { propagacja } \\
\text { „W dół” }\end{array}$} \\
\hline $2 T[\mathrm{~s}] \rightarrow$ & 0,7692 & 1,4081 & 2,0033 & \\
\hline$R[\mathrm{~km}] \rightarrow$ & 2,400 & 2,487 & 4,400 & \multirow{2}{*}{$\begin{array}{l}\text { propagacja } \\
\text { „W górę" }\end{array}$} \\
\hline $2 T[\mathrm{~s}] \rightarrow$ & 0,600 & 0,6605 & 1,2983 & \\
\hline
\end{tabular}

Tablica 1. Wyniki obliczeń programu MIKROMOD 3D dla pozycji szczelinowania $r=0,0 \mathrm{~km}$ W azymucie $\varphi=0^{\circ}$ - propagacja „W dół” (a) i „,W górę” (b) oraz dla pozycji szczelinowania $r=0,800 \mathrm{~km}$ w azymucie $\varphi=0^{\circ}$ - propagacja ,w dół” (c) i ,w górę” (d)

\begin{tabular}{|c|c|c|c|c|c|c|c|c|c|c|}
\hline \multirow[t]{2}{*}{ (a) } & $f i=$ & 0. & \multicolumn{3}{|c|}{$r=0.000 \mathrm{~km}$} & & & & \multicolumn{2}{|c|}{ propagacja w dół } \\
\hline & $\mathrm{r}$ & $\mathrm{x}_{\mathrm{km}}$ & $\mathrm{YO}$ & $\mathrm{zo}$ & $x_{\mathrm{km}}$ & $\mathrm{Y}_{\mathrm{km}}$ & $\mathrm{z}_{\mathrm{km}}$ & $\mathrm{R}_{\mathrm{km}}$ & ${ }^{T}{ }_{s}$ & $E_{J}$ \\
\hline 1. gr. & .000 & 1.850 & 2.138 & .000 & 1.850 & 2.138 & .000 & 2.000 & .7692 & $.1250 \mathrm{E}+04$ \\
\hline 2. gr. & .000 & 1.850 & 2.138 & .000 & 1.766 & 2.138 & .000 & 3.916 & 1.4081 & $.3260 \mathrm{E}+03$ \\
\hline 3. gr. & $\begin{array}{l}.000 \\
.093\end{array}$ & 1.850 & 2.138 & .000 & 1.830 & 2.138 & .000 & 6.000 & 2.0033 & $.1389 E+03$ \\
\hline
\end{tabular}

\begin{tabular}{|c|c|c|c|c|c|c|c|c|c|c|}
\hline \multirow[t]{2}{*}{ (b) } & $f i=$ & 0 . & \multicolumn{3}{|c|}{$\mathrm{r}=0.000 \mathrm{~km}$} & & & & \multicolumn{2}{|c|}{ propagacja w górę } \\
\hline & $\mathrm{r}_{\mathrm{km}}$ & $x_{\mathrm{km}}$ & $\mathrm{YO}_{\mathrm{km}}$ & $\underset{\mathrm{km}}{\mathrm{zo}}$ & $x_{k m}$ & $Y_{\mathrm{km}}$ & $\mathrm{z}_{\mathrm{km}}$ & ${ }_{\mathrm{km}}^{\mathrm{R}}$ & ${ }^{T}{ }_{S}$ & $E_{J}$ \\
\hline 1. gr. & .000 & 1.850 & 2.138 & 3.200 & 1.850 & 2.138 & 3.200 & 2.400 & .6000 & $.8681 \mathrm{E}+03$ \\
\hline 2. gr. & $\begin{array}{r}-.093 \\
-.000 \\
-.087\end{array}$ & 1.850 & 2.138 & -3.200 & 1.909 & 2.138 & 3.200 & 2.487 & .6605 & $.8085 E+03$ \\
\hline 3. gr. & $\begin{array}{r}.000 \\
-.000\end{array}$ & 1.850 & 2.138 & -3.200 & 1.834 & 2.138 & 3.200 & 4.400 & 1.2983 & $.2583 E+03$ \\
\hline
\end{tabular}

\begin{tabular}{|c|c|c|c|c|c|c|c|c|c|c|}
\hline \multirow[t]{2}{*}{ (c) } & $f i=$ & 0. & \multicolumn{3}{|c|}{$r=0.800 \mathrm{~km}$} & & & & \multicolumn{2}{|c|}{ propagacja w dół } \\
\hline & $\mathrm{r}$ & $\mathrm{x}_{\mathrm{km}}$ & $\begin{array}{l}\mathrm{YO} \\
\mathrm{km}\end{array}$ & $\mathrm{zo}$ & $x_{\mathrm{km}}$ & $Y_{\mathrm{km}}$ & $z_{k m}$ & $\mathrm{R}_{\mathrm{km}}$ & $T_{S}$ & $E_{J}$ \\
\hline 1. gr. & .800 & 1.850 & 2.938 & .000 & 1.850 & 1.338 & .000 & 2.561 & .9851 & $.7622 \mathrm{E}+03$ \\
\hline gr. & .800 & 1.850 & 2.938 & .000 & 1.770 & -.655 & .000 & 5.326 & 1.9066 & $.1763 E+03$ \\
\hline 3. gr. & .800 & 1.850 & 2.938 & .000 & 1.800 & -3.894 & .000 & 9.177 & 3.0070 & $.5936 E+02$ \\
\hline
\end{tabular}

\begin{tabular}{|c|c|c|c|c|c|c|c|c|c|}
\hline \multirow{2}{*}{ (d) } & 0. & \multicolumn{3}{|c|}{$\mathrm{r}=0.800 \mathrm{~km}$} & & & & \multicolumn{2}{|c|}{ propagacja w górę } \\
\hline & $\underset{\mathrm{km}}{\mathrm{x}}$ & $\stackrel{\mathrm{YO}}{\mathrm{km}}$ & $\mathrm{zo}$ & $x_{\mathrm{km}}$ & $Y_{\mathrm{km}}$ & $\mathrm{z}_{\mathrm{km}}$ & ${ }_{\mathrm{km}}^{\mathrm{R}}$ & $T_{S}$ & $E_{J}$ \\
\hline .800 & 1.850 & 2.938 & 3.200 & 1.850 & 1.338 & 3.200 & 2.884 & .7211 & $.6010 E+03$ \\
\hline $\begin{array}{r}.093 \\
-.800 \\
-.087\end{array}$ & 1.850 & 2.938 & -3.200 & 1.909 & 1.401 & 3.200 & 2.926 & .7758 & $.5842 \mathrm{E}+03$ \\
\hline $\begin{array}{l}\text { 3. gr. } \begin{array}{r}.000 \\
-.118\end{array}\end{array}$ & 1.850 & 2.938 & -3.200 & 1.830 & .526 & 3.200 & 5.030 & 1.4772 & $.1977 E+03$ \\
\hline
\end{tabular}


zaś dla odległości szczelinowania $r=800 \mathrm{~m}$ i azymutu $\varphi=270^{\circ}$ są następujące:

\begin{tabular}{|lc|c|c|c|}
\cline { 2 - 4 } \multicolumn{1}{c|}{} & 1. granica & 2. granica & 3. granica & \multicolumn{1}{c}{} \\
\cline { 1 - 4 }$R[\mathrm{~km}] \rightarrow$ & 2,561 & 5,163 & 9,128 & propagacja \\
\cline { 1 - 4 } $2 T[\mathrm{~s}] \rightarrow$ & 0,9851 & 1,8507 & 2,9825 & „W dół” \\
\cline { 1 - 4 }$R[\mathrm{~km}] \rightarrow$ & 2,884 & 2,968 & 5,018 & propagacja \\
\cline { 1 - 4 } $2 T[\mathrm{~s}] \rightarrow$ & 0,7211 & 0,7875 & 1,4727 & "W górę" \\
\hline
\end{tabular}

co potwierdzają wyniki obliczeń programu MIKROMOD 3D - tablica 2 (a, b, c, d).

Ponadto, jak widać z tablic 1 i 2 przytoczonych dla modelu 2, nie obserwujemy zróżnicowania wartości całkowitej drogi promienia $R$ oraz czasu propagacji jako funkcji azymutu, natomiast zwracają uwagę różnice wynikające z odległości położenia punktu wzbudzania drgań (szczelinowania), wzrastające z głębokością granic (powierzchni rozdzielających). Głębokość granicy imituje pozycję schematu akwizycji, co komentują wyniki realizacji programu (tablice 1 i 2).

Ilustrację wyników dla omawianego modelu 2 przedstawiono na rysunku 7c w [1] w postaci tras sejsmicznych (splot współczynników odbicia z sygnałem teoretycznym), uporządkowanych względem kątów azymutu $0 \div 360^{\circ}$ (liczonych z krokiem $90^{\circ}$ ), dla kolejnych trzech granic i dla kolejnych promieni $r_{i}$ okręgu sterującego $\mathrm{w}$ zakresie od 0 do $800 \mathrm{~m}$. W zależności od głębokości granicy odbijającej rejestrowany czas podwójny wzrasta wraz z promieniem okręgu (około $230 \mathrm{~ms}$ dla pierwszej granicy, $500 \mathrm{~ms}$ dla drugiej, do $1000 \mathrm{~ms}$ dla trzeciej) - w przypadku propagacji „,w dół” - oraz o około $150 \mathrm{~ms}$ do $200 \mathrm{~ms}$ w przypadku propagacji „do góry”, gdzie sukcesja warstw pozostaje niezmieniona. Przedstawione na rysunku 7c w [1] uporządkowanie sejsmogramów zgodnie z wartością kąta azymutu imituje rejestrację drgań mikrosejsmicznych liniowym rozstawem odbiorników wzdłuż określonego kierunku, co może mieć zastosowanie w odniesieniu do warstw wyraźnie anizotropowych.

Model 3 był obiektem, na którym ponadto testowano dwie opcje zaprojektowanego schematu akwizycji (z ograniczeniem obszaru rejestracji oraz bez ograniczenia). Przyjmując głębokość horyzontu szczelinowania równą 4,700 km (głębokość punktu wzbudzenia) oraz wielkość okręgu sterującego równą 4,0 km, przy postępie punktów szczelinowania o krok $d r$ równy $500 \mathrm{~m}$ i dla kąta azymutu $=0^{\circ}$, przestrzeń rejestracji w przypadku propagacji „,w górę” sięga zaledwie

Tablica 2. Wyniki obliczeń programu MIKROMOD 3D dla pozycji szczelinowania $r=0,0 \mathrm{~km}$ w azymucie $\varphi=270^{\circ}$ - propagacja „w dół” (a) i „,w górę" (b) oraz dla pozycji szczelinowania $r=0,800 \mathrm{~km}$ w azymucie $\varphi=270^{\circ}-$ propagacja „w dół” (c) i „w górę” (d)

\begin{tabular}{|c|c|c|c|c|c|c|c|c|c|c|}
\hline \multirow[t]{2}{*}{ (a) } & \multicolumn{2}{|c|}{$f i=270$} & \multicolumn{3}{|c|}{$r=0.000 \mathrm{~km}$} & & & & \multicolumn{2}{|c|}{ propagacja w dół } \\
\hline & $\mathrm{r}$ & $\begin{array}{c}\times 0 \\
\mathrm{~km}\end{array}$ & $\begin{array}{c}\mathrm{Y} 0 \\
\mathrm{~km}\end{array}$ & $\mathrm{zo}$ & $x_{k m}$ & $Y_{\mathrm{km}}$ & $\mathrm{z}_{\mathrm{km}}$ & ${ }_{\mathrm{km}}^{\mathrm{R}}$ & $T_{S}$ & $E_{J}$ \\
\hline & & 1.850 & 2.138 & .000 & 1.850 & 2.138 & .000 & 2.000 & .7692 & $.1250 \mathrm{E}+04$ \\
\hline & & 1.850 & 2.138 & .000 & 1.766 & 2.138 & .000 & 3.916 & 1.4081 & $.3260 E+03$ \\
\hline & $\begin{array}{r}.087 \\
.000 \\
.093\end{array}$ & 1.850 & 2.138 & .000 & 1.830 & 2.138 & .000 & 6.000 & 2.0033 & $.1389 E+03$ \\
\hline
\end{tabular}

\begin{tabular}{|c|c|c|c|c|c|c|c|c|c|c|}
\hline \multirow[t]{2}{*}{ (b) } & \multicolumn{2}{|c|}{$f i=270}$. & \multicolumn{3}{|c|}{$\mathrm{r}=0.000 \mathrm{~km}$} & \multirow[b]{2}{*}{$\mathrm{Y}_{\mathrm{km}}$} & \multirow[b]{2}{*}{$\mathrm{z}_{\mathrm{km}}$} & \multirow[b]{2}{*}{$\mathrm{R}_{\mathrm{km}}$} & \multicolumn{2}{|c|}{ propagacja w górę } \\
\hline & $\mathrm{km}$ & $\begin{array}{c}x 0 \\
\mathrm{~km}\end{array}$ & $\stackrel{\mathrm{YO}}{\mathrm{km}}$ & $\mathrm{zo}$ & $x_{\mathrm{km}}$ & & & & ${ }^{T} \mathrm{~s}$ & $E_{J}$ \\
\hline 1. gr. & .000 & 1.850 & 2.138 & 3.200 & 1.850 & 2.138 & 3.200 & 2.400 & .6000 & $.8681 E+03$ \\
\hline 2. gr. & $\begin{array}{r}.000 \\
.007\end{array}$ & 1.850 & 2.138 & -3.200 & 1.909 & 2.138 & 3.200 & 2.487 & .6605 & $.8085 E+03$ \\
\hline 3. gr. & $\begin{array}{r}.000 \\
-.118\end{array}$ & 1.850 & 2.138 & -3.200 & 1.834 & 2.138 & 3.200 & 4.400 & 1.2983 & $.2583 E+03$ \\
\hline
\end{tabular}

\begin{tabular}{|c|c|c|c|c|c|c|c|c|c|c|}
\hline \multirow[t]{2}{*}{ (c) } & \multicolumn{2}{|c|}{$f i=270}$. & \multicolumn{3}{|c|}{$\mathrm{r}=0.800 \mathrm{~km}$} & & & & \multicolumn{2}{|c|}{ propagacja w dół } \\
\hline & $\begin{array}{l}\mathrm{r} \\
\mathrm{km}\end{array}$ & $\mathrm{x}_{\mathrm{km}}$ & $\begin{array}{l}\mathrm{YO} \\
\mathrm{km}\end{array}$ & $\mathrm{zo}_{\mathrm{km}}$ & $x_{\mathrm{km}}$ & $\mathrm{Y}_{\mathrm{km}}$ & $z_{\mathrm{km}}$ & $\mathrm{R}_{\mathrm{km}}$ & $T_{S}$ & $E_{J}$ \\
\hline 1. gr. & .800 & 1.050 & 2.138 & .000 & 2.650 & 2.137 & .000 & 2.561 & .9851 & $.7622 E+03$ \\
\hline 2. gr. & .800 & 1.050 & 2.138 & .000 & 4.451 & 2.137 & .000 & 5.163 & 1.8507 & $.1875 E+03$ \\
\hline 3. gr. & $\begin{array}{l}.800 \\
.093\end{array}$ & 1.050 & 2.138 & .000 & 7.818 & 2.137 & .000 & 9.128 & 2.9825 & $.6000 \mathrm{E}+02$ \\
\hline
\end{tabular}

\begin{tabular}{|c|c|c|c|c|c|c|c|c|c|c|}
\hline \multirow{2}{*}{ (d) } & \multicolumn{2}{|c|}{$f i=270$} & \multicolumn{3}{|c|}{$\mathrm{r}=0.800 \mathrm{~km}$} & & & & \multicolumn{2}{|c|}{ propagacja w górę } \\
\hline & $\mathrm{r}_{\mathrm{km}}$ & $\begin{array}{c}x_{0} \\
\mathrm{~km}\end{array}$ & $\underset{\mathrm{km}}{\mathrm{YO}}$ & $\mathrm{zo}$ & $x_{k m}$ & $Y_{\mathrm{km}}$ & $z_{k m}$ & ${ }^{R}{ }_{k m}$ & $T_{s}$ & $E_{J}$ \\
\hline & & 1.050 & 2.138 & 3.200 & 2.650 & 2.137 & 3.200 & 2.884 & .7211 & $.6010 E+03$ \\
\hline & $\begin{array}{r}.030 \\
-.087\end{array}$ & 1.050 & 2.138 & -3.200 & 2.668 & 2.137 & 3.200 & 2.968 & .7875 & $.5677 \mathrm{E}+03$ \\
\hline & $\begin{array}{r}.800 \\
-.118\end{array}$ & 1.050 & 2.138 & -3.200 & 3.438 & 2.137 & 3.200 & 5.018 & 1.4727 & $.1986 \mathrm{E}+03$ \\
\hline
\end{tabular}




\section{WIZUALIZACJA WYNIKÓW}

Sukcesja wyników

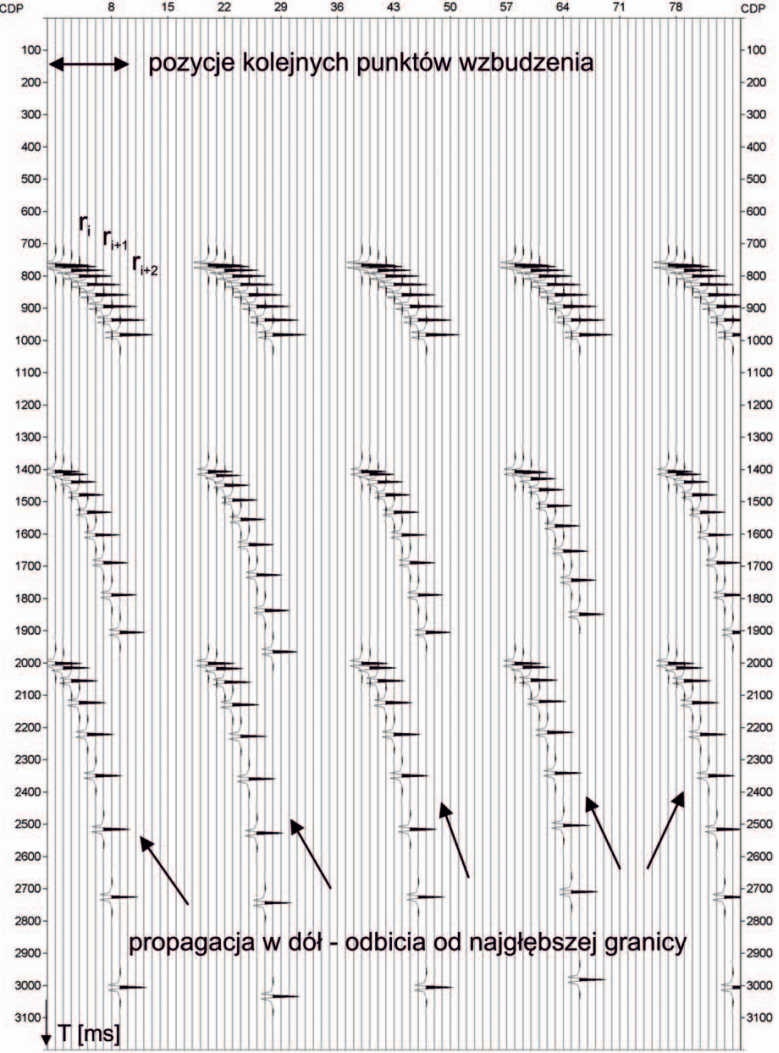

pierwszego punktu obserwacji $(r=0,00 \mathrm{~km})$ i wszystkich powierzchni modelu, ale już w przypadku odległości $r=0,5 \mathrm{~km}$ punkty obserwacji leżą poza obszarem akwizycji ograniczonych do kwadratu $[15 \cdot 15] \mathrm{km}\left(\frac{0,00 \leq x \leq 15 \mathrm{~km}}{0,00 \leq y \leq 15 \mathrm{~km}}\right)$. Natomiast dla azymutu $=180^{\circ}$ zakres obserwacji osiąga odległość

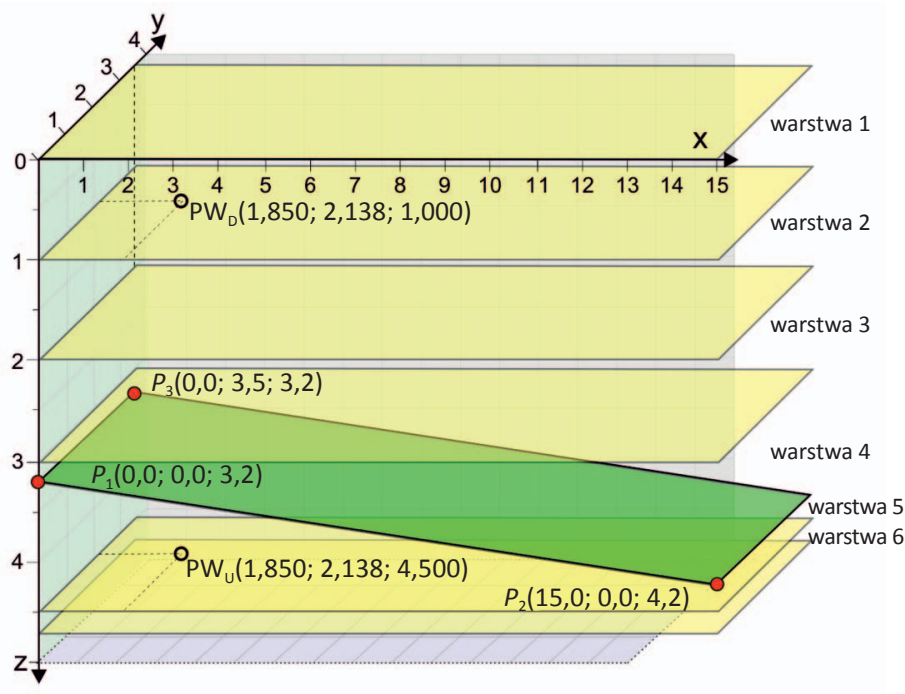

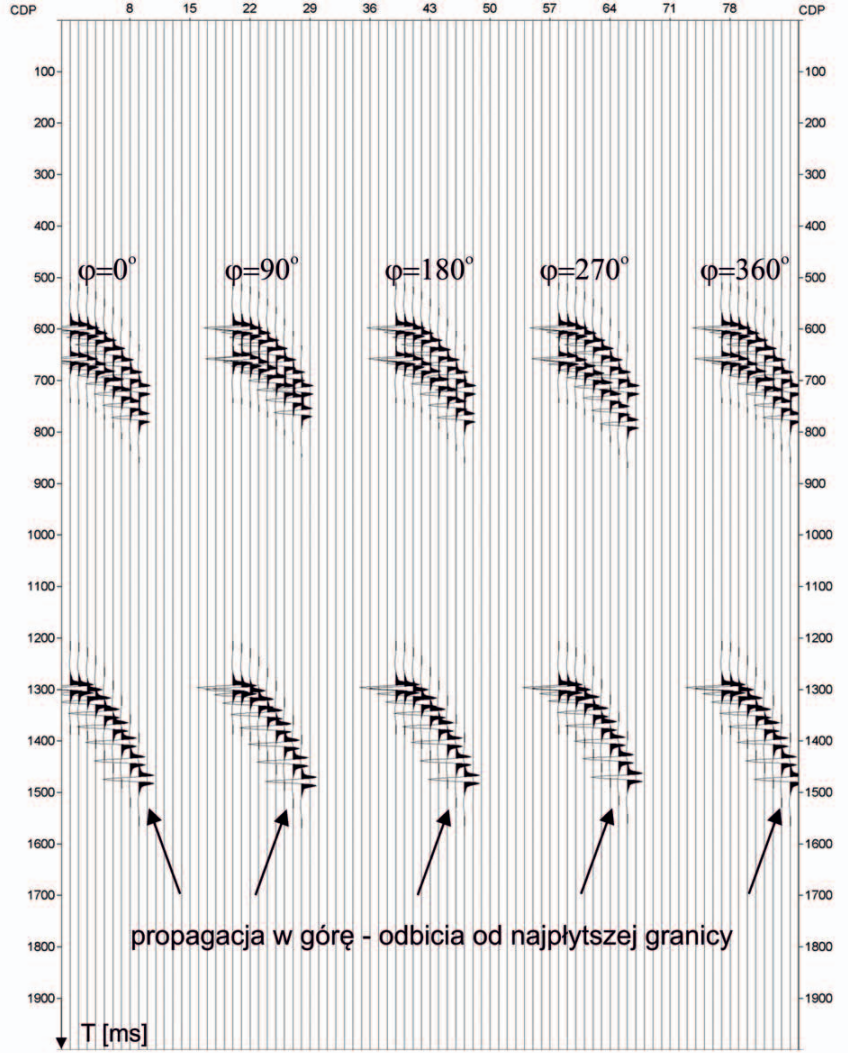

2,0 km i stopniowo maleje wraz ze wzrostem kąta fi. Dla przypadku propagacji „,w dół”, czyli dla poziomu wzbudzenia $z=0,00$, obszar propagacji również nie przekraczał $1500 \mathrm{~m}$.

W przypadku realizacji programu w opcji „bez ograniczenia obszaru rejestracji” każda pozycja punktu wzbudzenia (w zakresie 0,0 do 4,0 km) umożliwia zlokalizowanie punktu

\begin{tabular}{|c|c|c|c|c|c|}
\hline Powierzchnia & $A x$ & By & $C z$ & $D$ & \\
\hline 1 & 0,0 & 0,0 & 1,0 & 0,0 & $z=0 \mathrm{~km}$ \\
\hline 2 & 0,0 & 0,0 & 1,0 & $-1,0$ & $z=-1$ \\
\hline 3 & 0,0 & 0,0 & 1,0 & $-2,0$ & $z=-2$ \\
\hline 4 & 0,0 & 0,0 & 1,0 & $-3,0$ & $z=-3$ \\
\hline 5 & $-3,5$ & 0,0 & 52,5 & $-168,0$ & $\begin{array}{l}\text { granica nachylona } \\
3,2 \leq z \leq 4,2\end{array}$ \\
\hline 6 & 0,0 & 0,0 & 1,0 & $-4,5$ & $z=-4,5$ \\
\hline 7 & 0,0 & 0,0 & 1,0 & $-4,7$ & $z=-4,7$ \\
\hline
\end{tabular}

Granicę nachyloną określono na podstawie trzech punktów:

\begin{tabular}{|c|c|c|c|}
\hline Nr punktu & $x$ & $y$ & $z$ \\
\hline$P_{1}$ & 0,0 & 0,0 & 3,2 \\
\hline$P_{2}$ & 15,0 & 0,0 & 4,2 \\
\hline$P_{3}$ & 3,0 & 3,5 & 3,2 \\
\hline
\end{tabular}

Geometria modelu 3 (liczba warstw: 6; liczba powierzchni rozgraniczających: 7) 

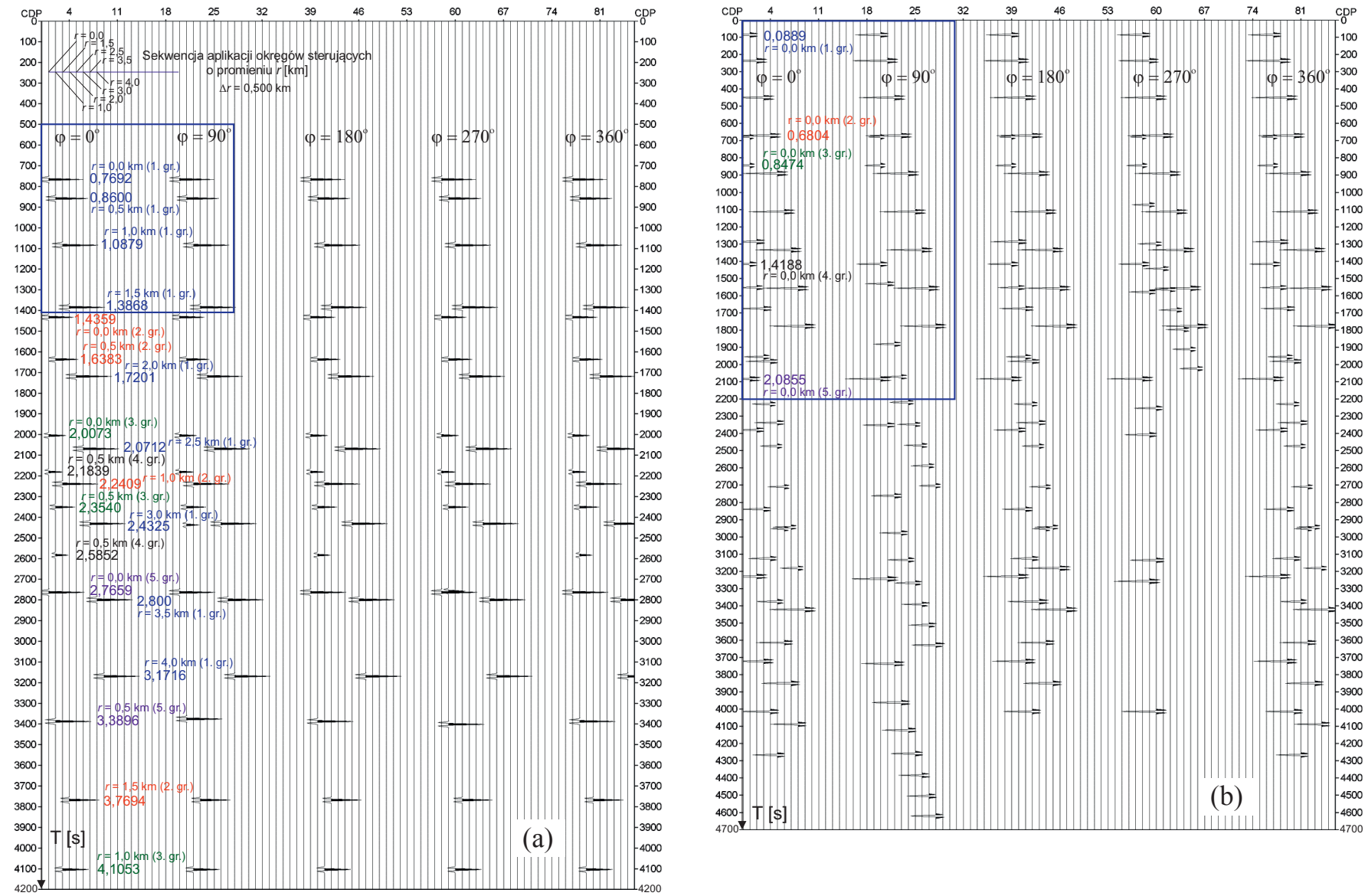

Rys. 1. Modelowany zapis rejestracji drgań wywołanych wzbudzeniem na powierzchni o głębokości $0,0 \mathrm{~km}$ (propagacja „w dół”) (a) oraz o głębokości wzbudzenia 4,5 km (propagacja „w górę”) (b) - obszar rejestracji nieograniczony (fragmenty powiększone poniżej)

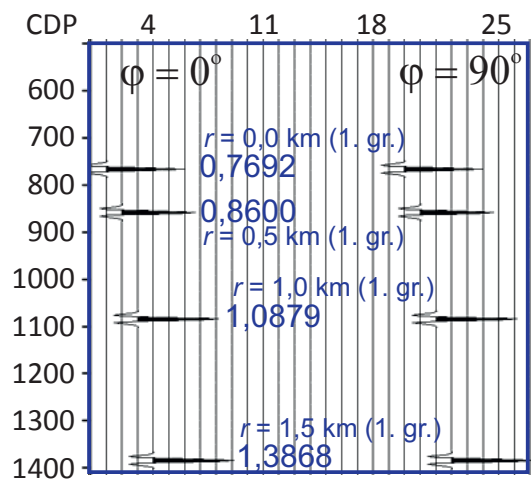

W powiększeniu: sekwencja refleksów wzbudzonych w kolejnych pozycjach szczelinowania $(r=0,0 \mathrm{~km}$, $r=0,5 \mathrm{~km}, r=1,5 \mathrm{~km}$ ) załamanych (odbitych) na pierwszej powierzchni ośrodka

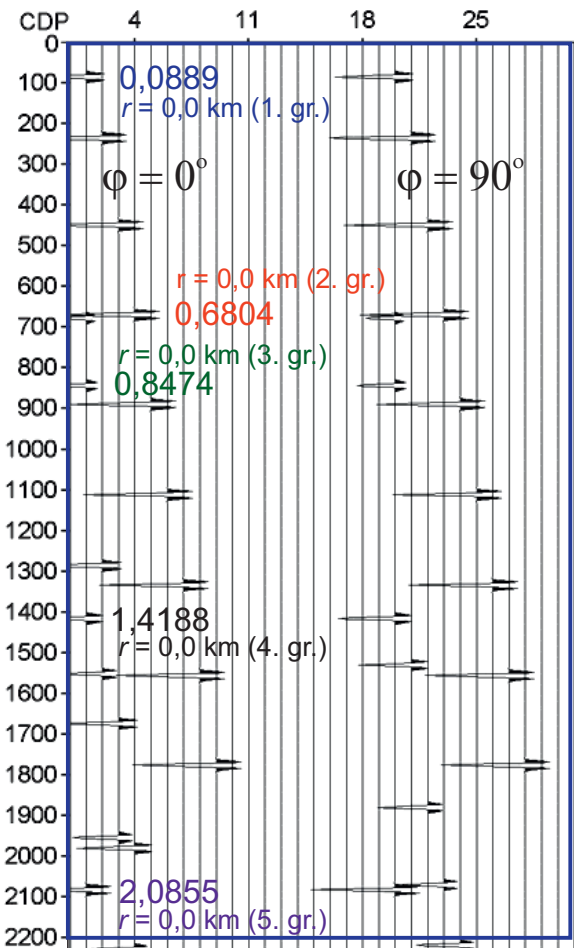

W powiększeniu: sekwencja refleksów wzbudzonych w pierwszej pozycji szczelinowania i odbitych (załamanych) na kolejnych powierzchniach ośrodka 

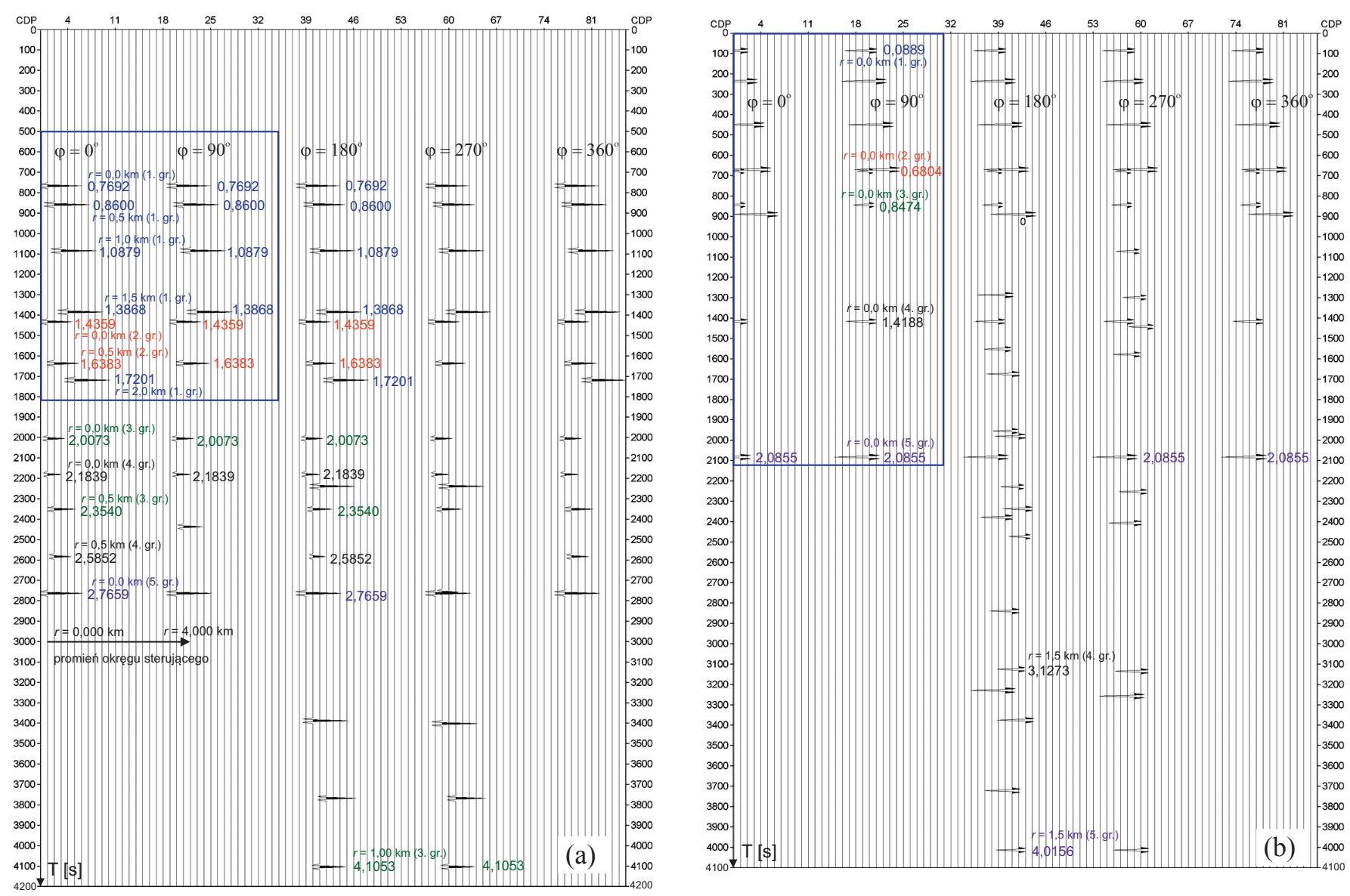

Rys. 2. Modelowany zapis rejestracji drgań wywołanych wzbudzeniem na powierzchni o głębokości 0,0 km (propagacja „W dół”) (a) oraz o głębokości wzbudzenia 4,5 km (propagacja „w górę”) (b) - obszar rejestracji ograniczony

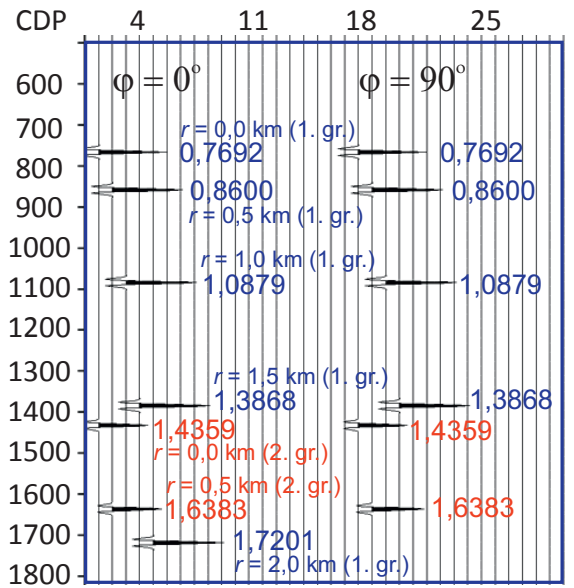

W powiększeniu: sekwencja refleksów wzbudzonych w kolejnych pozycjach szczelinowania $(r=0,0 \mathrm{~km}$, $r=0,5 \mathrm{~km}, r=1,5 \mathrm{~km}$ ) załamanych (odbitych) na pierwszej powierzchni ośrodka

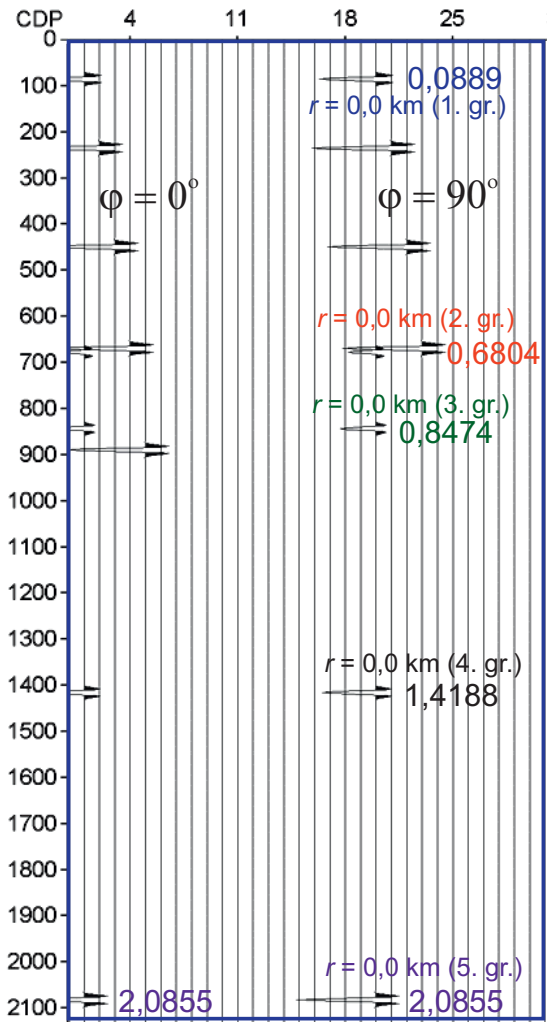

W powiększeniu: sekwencja refleksów wzbudzonych w pierwszej pozycji szczelinowania i odbitych (załamanych) na kolejnych powierzchniach ośrodka 
obserwacji, co jest przedmiotem monitoringu, pomimo że współrzędne i całkowita droga promienia wykraczają poza występujące w praktyce i akceptowane wartości. Tak np. dla propagacji promienia „,W górę", dla promienia sterującego $1,0 \mathrm{~km}$ i azymutu $\mathrm{fi}=90^{\circ}$ całkowita długość promienia wynosi ponad $17 \mathrm{~km}$, a czas rejestracji przekracza 4,5 s.

Analogicznie w przypadku propagacji „,w dół” najdłuższa droga propagacji wynosi $12,8 \mathrm{~km}$ i odpowiada czasowi

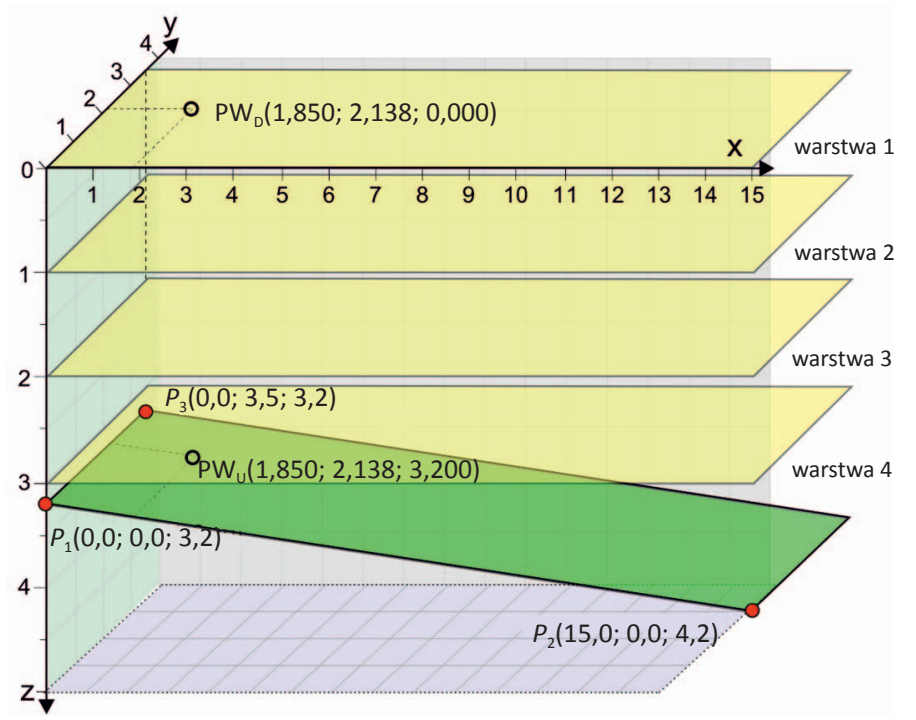

około 4,2 s. Taka rozbieżność wyników każe przypuszczać, że nie można porównywać energii drgań o wstępnie założonej wielkości początkowej $E_{0}$, które różnią się tak znacznie drogą propagacji, chociażby ze względu na thumienie, różniące się o trzy rzędy wielkości - ponad $1000 \mathrm{razy}\left(E_{r=0 \mathrm{~km}}=\right.$ $\left.=0,312 \mathrm{E}+05, E_{r=1 \mathrm{~km}}=0,406 \mathrm{E} 02, E_{r=3,5 \mathrm{~km}}=0,1804 \mathrm{E} 02\right)$.

Ilustrację powyższych przypadków stanowią rysunki 1 (a, b) i 2 (a, b), na których przedstawiono sejsmogramy

\begin{tabular}{|c|c|c|c|c|c|}
\hline Powierzchnia & $A x$ & By & $C z$ & $D$ & \\
\hline 1 & 0,0 & 0,0 & 1,0 & 0,0 & $z=0 \mathrm{~km}$ \\
\hline 2 & 0,0 & 0,0 & 1,0 & $-1,0$ & $z=-1$ \\
\hline 3 & 0,0 & 0,0 & 1,0 & $-2,0$ & $z=-2$ \\
\hline 4 & 0,0 & 0,0 & 1,0 & $-3,0$ & $z=-3$ \\
\hline 5 & $-3,5$ & 0,0 & 52,5 & $-168,0$ & $\begin{array}{l}\text { granica nachylona } \\
3,2 \leq z \leq 4,2\end{array}$ \\
\hline
\end{tabular}

\begin{tabular}{|c|c|c|c|}
\hline Nr punktu & $x$ & $y$ & $z$ \\
\hline$P_{1}$ & 0,0 & 0,0 & 3,2 \\
\hline$P_{2}$ & 15,0 & 0,0 & 4,2 \\
\hline$P_{3}$ & 3,0 & 3,5 & 3,2 \\
\hline
\end{tabular}

Geometria modelu 4 z nachyloną warstwą szczelinowaną (liczba warstw: 4; liczba powierzchni rozgraniczających: 5)

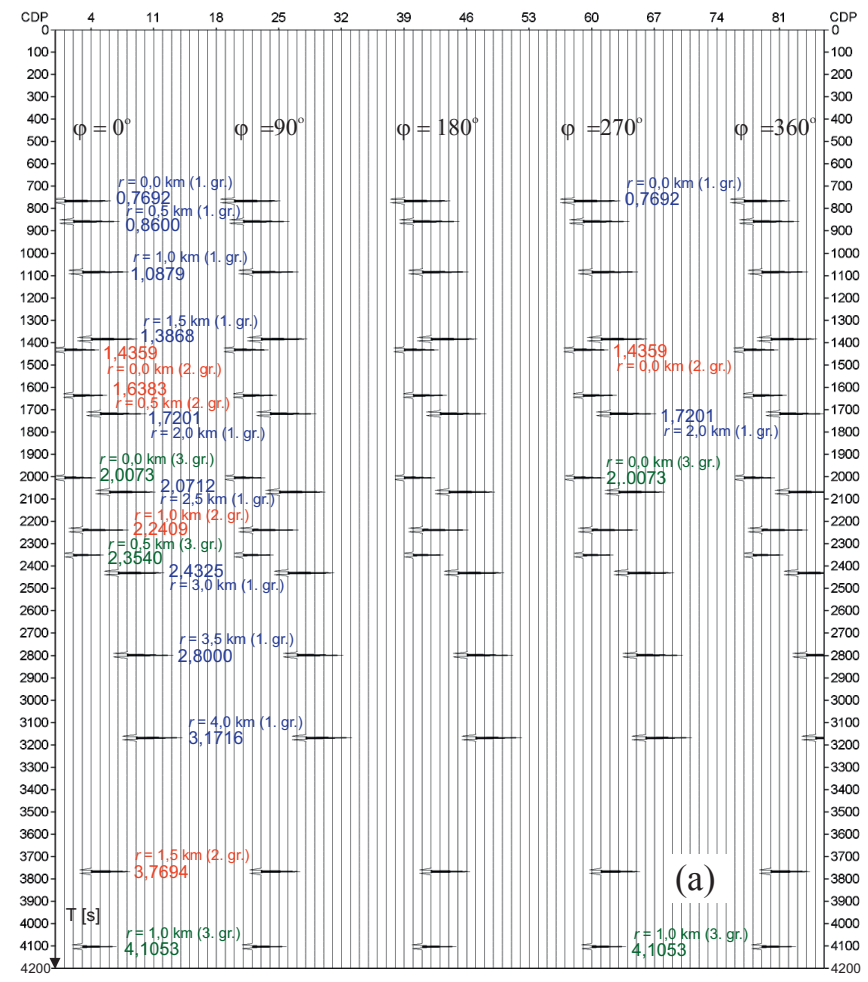

Rys. 3. Modelowany zapis rejestracji drgań wywołanych wzbudzeniem na powierzchni o głębokości $0,0 \mathrm{~km}$ (propagacja ,w dół”) (a) oraz o głębokości wzbudzenia $3,2 \mathrm{~km}$ (propagacja „w górę") (b) - granica nachylona

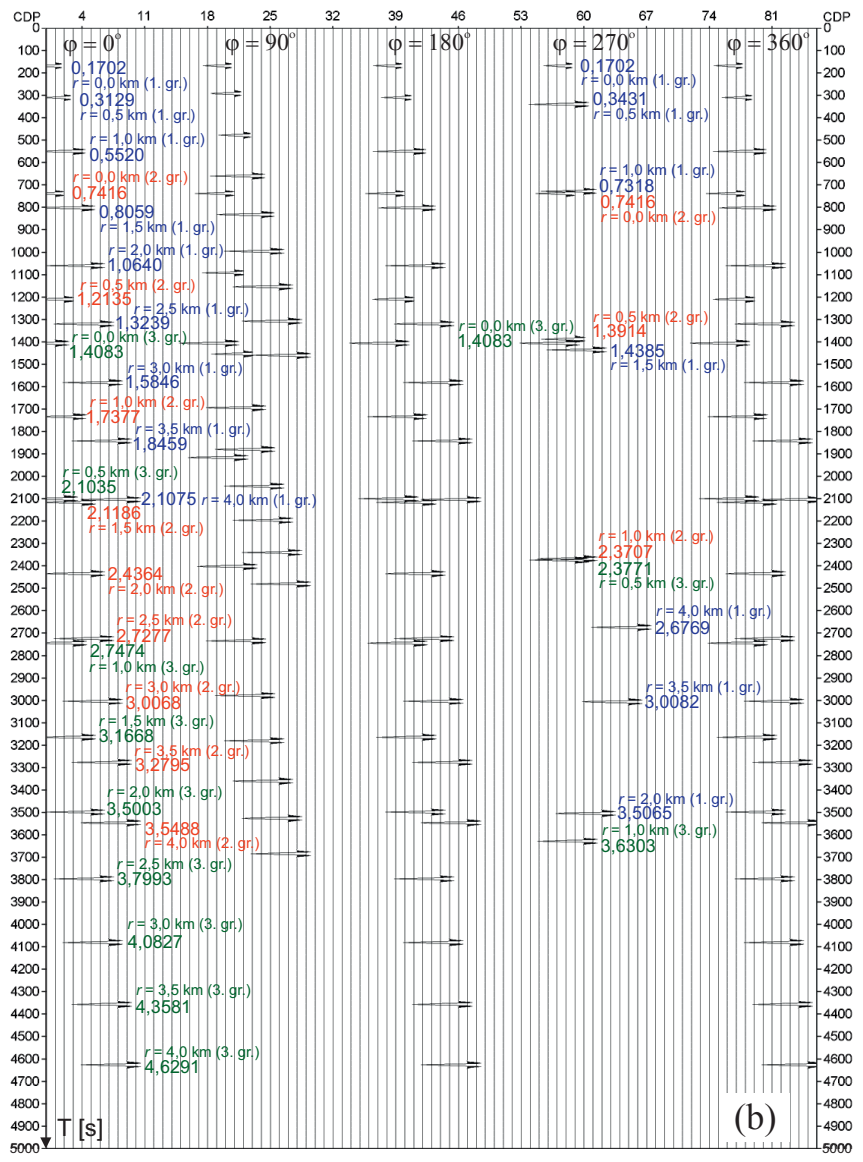


Tabela 3. Wyniki obliczeń programu MIKROMOD 3D dla modelu 4 z nachyloną powierzchnią szczelinowaną:

(a) propagacja „,W dół”, (b) propagacja „w górę”

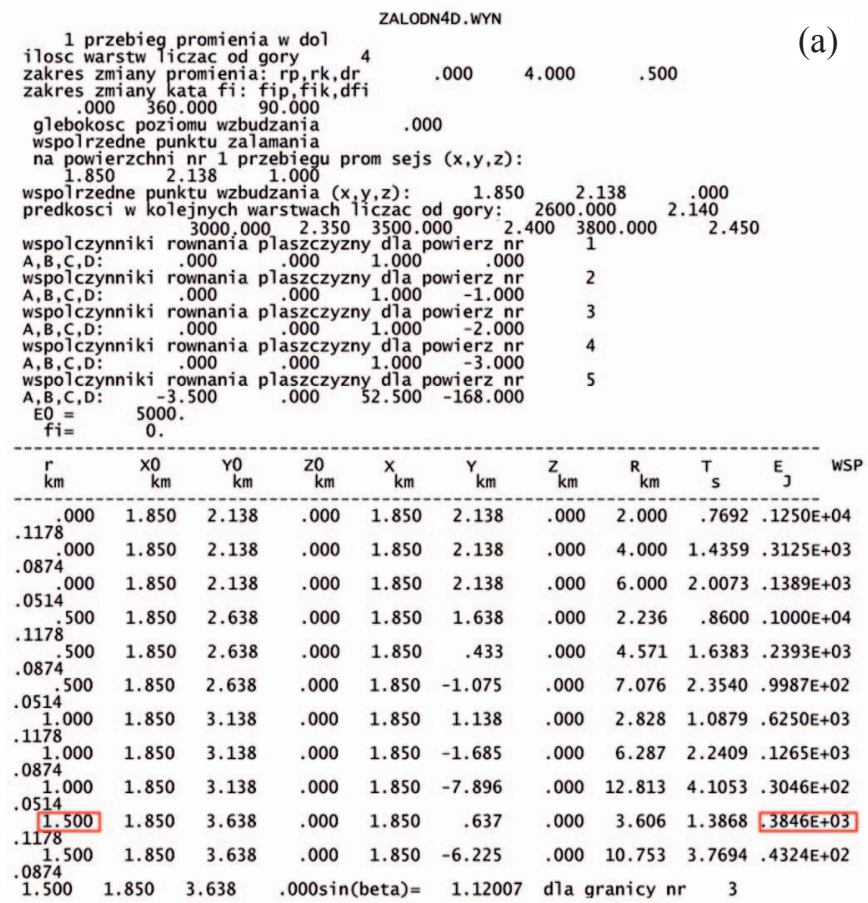

ZALODN4D. WYN

\begin{tabular}{|c|c|c|c|c|c|c|c|c|c|}
\hline$\stackrel{\mathrm{r}}{\mathrm{km}}$ & & & & $x_{k m}$ & $\mathrm{Y}_{\mathrm{km}}$ & $\mathrm{z}_{\mathrm{km}}$ & $\mathrm{R}_{\mathrm{km}}$ & $T_{s}$ & $E_{j}$ \\
\hline & 1.850 & 2.138 & .000 & 1.850 & 2.138 & .000 & 2.000 & .7692 & $.1250 \mathrm{E}+04$ \\
\hline & 1.850 & 2.138 & .000 & 1.850 & 2.138 & .000 & 4.000 & 1.4359 & $.3125 E+03$ \\
\hline & 1.850 & 2.138 & .000 & 1.850 & 2.138 & .000 & 6.000 & 2.0073 & $.1389 \mathrm{E}+03$ \\
\hline & 2.350 & 2.137 & .000 & 1.350 & 2.138 & .000 & 2.236 & .8600 & $.1000 E+04$ \\
\hline & 2.350 & 2.137 & .000 & .145 & 2.138 & .000 & 4.571 & 1.6383 & $.2393 E+03$ \\
\hline & 2.350 & 2.137 & .000 & -1.363 & 2.138 & .000 & 7.076 & 2.3540 & $.9987 E+02$ \\
\hline & 2.850 & 2.137 & .000 & .850 & 2.138 & .000 & 2.828 & 1.0879 & $.6250 E+03$ \\
\hline & 2.850 & 2.137 & .000 & -1.972 & 2.138 & .000 & 6.287 & 2.2409 & $.1265 E+03$ \\
\hline & 2.850 & 2.137 & .000 & -8.184 & 2.138 & .000 & 12.813 & 4.1053 & $.3046 E+02$ \\
\hline & 3.350 & 2.137 & .000 & .350 & 2.138 & .000 & 3.606 & 1.3868 & $.3846 E+03$ \\
\hline 0 & 3.350 & 2.137 & .000 & -6.512 & 2.138 & .000 & 10.753 & 3.7694 & $.4324 E+02$ \\
\hline & $\begin{array}{l}.350 \\
3.850\end{array}$ & $\begin{array}{l}2.137 \\
2.137\end{array}$ & $\begin{array}{c}.000 \sin \\
.000\end{array}$ & & & & & & $.2500 E+03$ \\
\hline
\end{tabular}

obserwowane dla różnych schematów akwizycji. Ograniczając obszar obserwacji, można równocześnie wyeliminować z udziału w monitoringu nieznaną część pola mikrosejsmicznego (stanowiącego efekt szczelinowania).

W przypadku ograniczenia obszaru rejestracji niektóre refleksy nie mogą być zarejestrowane, ponieważ droga propagującego promienia omija wyznaczoną strefę. Ten element koncepcji monitorowania mikrosejsmicznego jest istotnie różny od zasad występujących w metodzie sejsmicznej.

W metodzie sejsmicznej rejestrowane cechy pola sprężystego (czas, amplituda, częstotliwość) stanowią podstawę do określenia budowy geometrycznej i fizycznej ośrodka skalnego, natomiast w metodyce monitorowania mikrosejsmicznego badamy cechy mechaniczne (geomechaniczne) skał, a przede wszystkim ich podatność na działania

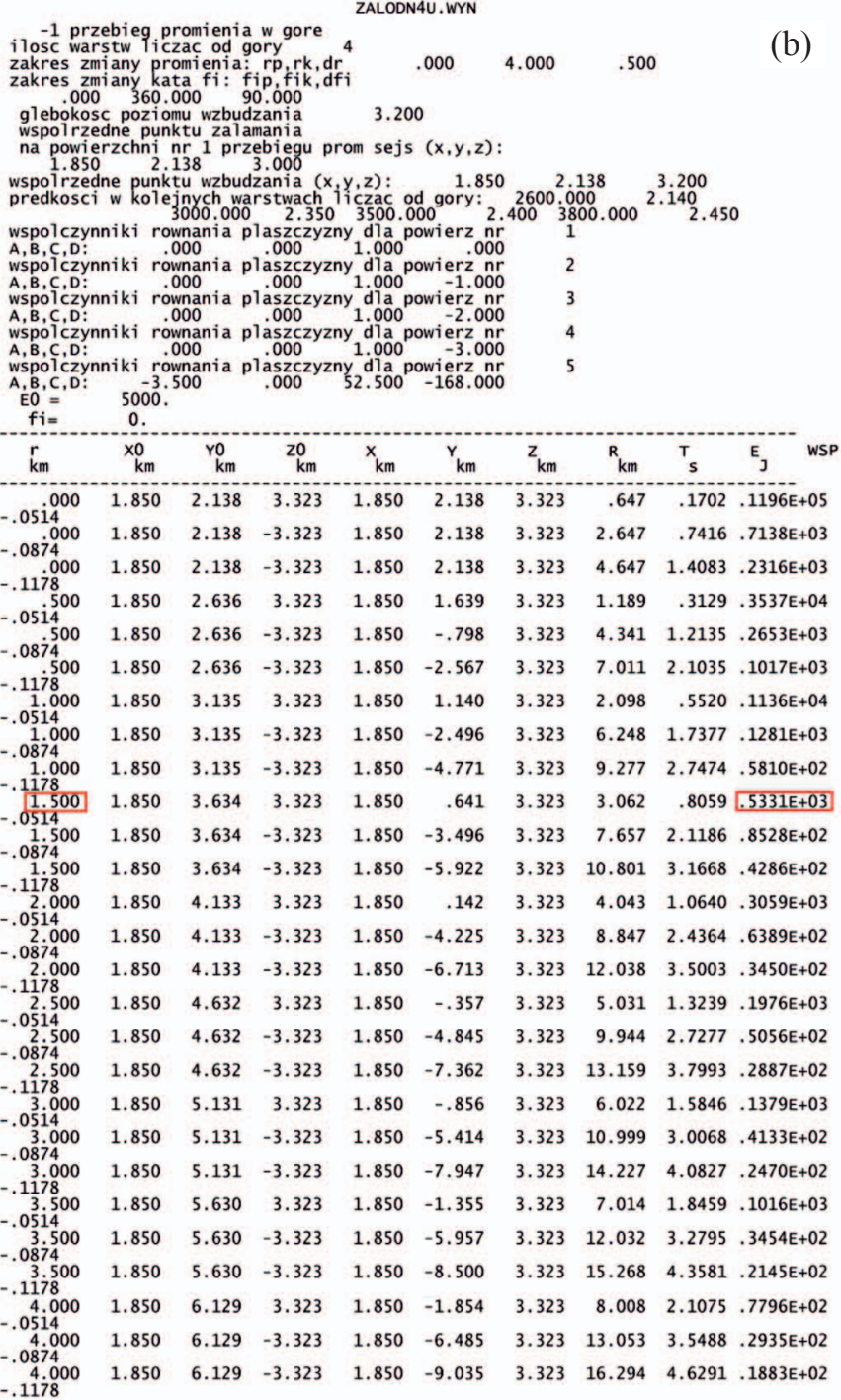

\begin{tabular}{|c|c|c|c|c|c|c|c|c|c|}
\hline \multicolumn{10}{|c|}{ ZALODN4U.WYN } \\
\hline $\mathrm{rm}_{\mathrm{km}}$ & $x_{0 m}$ & $\begin{array}{r}\mathrm{r}_{\mathrm{km}} \\
\mathrm{c}\end{array}$ & & $x_{\mathrm{km}}$ & $Y_{\mathrm{km}}$ & $\mathrm{z}_{\mathrm{km}}$ & ${ }_{\mathrm{Rm}}$ & $T_{s}$ & $\mathrm{E}_{\mathrm{J}}$ \\
\hline 000 & 1.850 & 2.138 & 3.323 & 1.850 & 2.138 & 3.323 & .647 & .1702 & $.1196 \mathrm{E}+05$ \\
\hline & 1.850 & 2.138 & -3.323 & 1.850 & 2.138 & 3.323 & 2.647 & .7416 & $.7138 \mathrm{E}+03$ \\
\hline & 1.850 & 2.138 & -3.323 & 1.850 & 2.138 & 3.323 & 4.647 & 1.4083 & $.2316 \mathrm{E}+03$ \\
\hline & 2.349 & 2.137 & 3.357 & 1.436 & 2.138 & 3.296 & 1.122 & .2952 & $.3973 E+04$ \\
\hline & 2.349 & 2.137 & -3.357 & -.634 & 2.138 & 3.158 & 3.905 & 1.0957 & $.3279 E+03$ \\
\hline & 2.349 & 2.137 & -3.357 & -2.167 & 2.138 & 3.056 & 6.338 & 1.9192 & $.1245 E+03$ \\
\hline & 2.848 & 2.137 & 3.390 & 1.143 & 2.138 & 3.276 & 1.830 & .4816 & $.1493 E+04$ \\
\hline & 2.848 & 2.137 & -3.390 & -1.709 & 2.138 & 3.086 & 5.200 & 1.4562 & $.1849 \mathrm{E}+03$ \\
\hline & 2.848 & 2.137 & -3.390 & -3.563 & 2.138 & 2.962 & 8.018 & 2.4049 & $.7778 E+02$ \\
\hline & 3.347 & 2.137 & 3.423 & .925 & 2.138 & 3.262 & 2.517 & .6624 & $.7892 \mathrm{E}+03$ \\
\hline & 3.347 & 2.137 & -3.423 & -2.173 & 2.138 & 3.055 & 6.077 & 1.6966 & $.1354 \mathrm{E}+03$ \\
\hline & 3.347 & 2.137 & -3.423 & -4.064 & 2.138 & 2.929 & 9.211 & 2.7371 & $.5894 E+02$ \\
\hline & 3.846 & 2.137 & 3.456 & .755 & 2.138 & 3.250 & 3.170 & .8342 & $.4975 E+03$ \\
\hline & 3.846 & 2.137 & -3.456 & -2.403 & 2.138 & 3.040 & 6.768 & 1.8836 & $.1091 \mathrm{E}+03$ \\
\hline & 3.846 & 2.137 & -3.456 & -4.269 & 2.138 & 2.915 & 10.102 & 2.9806 & $.4900 \mathrm{E}+02$ \\
\hline & 4.344 & 2.137 & 3.490 & .620 & 2.138 & 3.241 & 3.795 & .9987 & $.3471 E+03$ \\
\hline & 4.344 & 2.137 & -3.490 & -2.533 & 2.138 & 3.031 & 7.377 & 2.0468 & $.9187 \mathrm{E}+02$ \\
\hline & 4.344 & 2.137 & -3.490 & -4.362 & 2.138 & 2.909 & 10.850 & 3.1826 & $.4247 E+02$ \\
\hline & 4.843 & 2.137 & 3.523 & .510 & 2.138 & 3.234 & 4.399 & 1.1575 & $.2584 E+03$ \\
\hline & 4.843 & 2.137 & -3.523 & -2.613 & 2.138 & 3.026 & 7.945 & 2.1981 & $.7921 E+02$ \\
\hline & 4.843 & 2.137 & -3.523 & -4.404 & 2.138 & 2.906 & 11.521 & 3.3624 & $.3767 E+02$ \\
\hline & 5.342 & 2.137 & 3.556 & .419 & 2.138 & 3.228 & 4.985 & 1.3120 & $.2012 E+03$ \\
\hline & 5.342 & 2.137 & -3.556 & -2.667 & 2.138 & 3.022 & 8.491 & 2.3430 & $.6936 \mathrm{E}+02$ \\
\hline & 5.342 & 2.137 & -3.556 & -4.423 & 2.138 & 2.905 & 12.147 & 3.5292 & $.3389 \mathrm{E}+02$ \\
\hline & 5.841 & 2.137 & 3.589 & .342 & 2.138 & 3.223 & 5.559 & 1.4630 & $.1618 E+03$ \\
\hline & 5.841 & 2.137 & -3.589 & -2.706 & 2.138 & 3.020 & 9.023 & 2.4839 & $.6142 E+02$ \\
\hline & 5.841 & 2.137 & -3.589 & -4.429 & 2.138 & 2.905 & 12.743 & 3.6876 & $.3079 E+02$ \\
\hline
\end{tabular}


inżynierskie związane z udostępnieniem i eksploatacją złoża. W monitorowaniu uwaga musi być skupiona na rejestracji, analizie i interpretacji relacji ,energetycznych”, bowiem one świadczą o skuteczności szczelinowania.

Kolejnym testowanym przykładem jest model 4, przedstawiony na rysunku $11 \mathrm{w}$ publikacji [1]. Przeznaczony do szczelinowania odcinek części poziomej otworu znajduje się na powierzchni nachylonej o kącie upadu około $3,5^{\circ}$, zalegającej na głębokości $2,2 \div 3,2 \mathrm{~km}$.

Przypadek ten unaocznia, jak ważny jest przyjęty schemat monitorowania. Uzyskane wyniki przedstawiono na rysunku 3 (a, b).

Różny sposób propagacji (,w dół” lub „w górę”) sprawia, że rejestrujemy większą (lub mniejszą) część energii (z założenia identyczną w punkcie wzbudzenia), a drgania mikrosejsmiczne osiągają mniejsze (lub większe) zakresy propagacji, co widać na rysunku 3 i potwierdzone jest w tablicy 3.

Odsuwanie pozycji szczelinowania wzdłuż części horyzontalnej od części pionowej otworu przy zmianie kierunku propagacji (opcjonalnie rozważanie schematu akwizycji) skutkuje ograniczeniem odcinka szczelinowania do
1,5 km (propagacja „w dół”) w stosunku do założonego odcinka szczelinowania 4,0 km. Natomiast rejestrowane dla pozycji szczelinowania $r=1,5 \mathrm{~km}$ energie mikrowstrząsów dla propagacji „,w dół” i ,w górę” są porównywalne $(0,3846 \mathrm{E}+03$ - propagacja ,w dół” oraz $0,5331 \mathrm{E}+03$ - propagacja „w górę”), pomimo różnego czasu propagacji $T$ [s] $(1,3868 \mathrm{~s}$ oraz $0,8059 \mathrm{~s})$, ale zbliżonej całkowitej drogi propagacji $(R=3,606 \mathrm{~km} \mathrm{i} \mathrm{3,062} \mathrm{km).}$

Przedstawione rozważania wyraźnie pokazują, jak ważna jest rola modelowania mikrosejsmicznego dla - poprawnego i ukierunkowanego na określony obiekt i cel geologiczny - zaprojektowania lokalizacji przebiegu i parametrów szczelinowania hydraulicznego. Wykonane obliczenia pokazują zaledwie drobną część wielkiej niewiadomej zjawisk oraz procesów towarzyszących szczelinowaniu hydraulicznemu i chociaż pozornie są powszechnie znane i rozumiane, ilościowy ich opis jest trudny i daleki od doskonałości.

Stąd możliwość modelowania zjawisk towarzyszących szczelinowaniu, nawet w sposób przybliżony, stanowi narzędzie pierwszoplanowej wagi, zarówno w dziedzinie badań teoretycznych, jak też w codziennej praktyce przemysłowej.

Prosimy cytować jako: Nafta-Gaz 2016, nr 8, s. 587-596, DOI: 10.18668/NG.2016.08.01

Artykuł nadesłano do Redakcji 13.01.2016 r. Zatwierdzono do druku 6.04.2016 r.

Artykuł powstał na podstawie projektu badawczego pt. Wybór optymalnej technologii monitoringu mikrosejsmicznego w procesach szczelinowania hydraulicznego. Optymalizacja przetwarzania i interpretacji danych pomiarowych (GASLUPMIKROS) - obszar 2B. Zad. 2. Przetwarzanie i interpretacja danych mikrosejsmicznych oraz symulacje numeryczne fal generowanych w procesie szczelinowania hydraulicznego, w tym mikrosejsmika - aktywna i pasywna - w celu określenia dynamicznych zmian w ośrodku wywołanych procesami udostęniania i eksploatacji formacji tupkowych - praca INiG - PIB na zlecenie NCBiR; nr zlecenia 6113/SG, nr archiwalny: DK-4100-0601/10/13.

\section{Literatura}

[1] Jędrzejowska-Tyczkowska H.: Mikrosejsmika, sejsmika, sejsmologia - wspólne korzenie, różne cele, zintegrowane dziatania. Nafta-Gaz 2016, nr 7, s. 487-501.

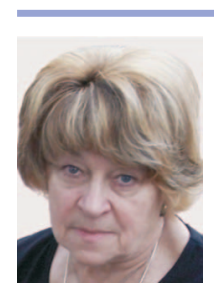

Prof. nzw. dr hab. inż. Halina JĘDRZEJOWSKA-TYCZKOWSKA

Instytut Nafty i Gazu - Państwowy Instytut Badawczy ul. Lubicz 25 A

31-503 Kraków

E-mail: tyczkowska@inig.pl 